\title{
D. G. Monrad og Tilbagetoget fra Dannevirke.
}

\author{
Af Erik Skram, $\uparrow$ \\ II.
}

Kl. 4, 7. Febr. stod Monrad i Rigsdagsfløjen paa det $\mathrm{i}$ Vinterdagens skumring lampelyse Christiansborg over for Eolketingets Medlemmer Ikke en Stol langs de grønt betrukne hesteskorundede Bordrakker var ubesat, ag Tilhørerbænkene og Logerne i Salens Baggrund var fyldt langt ud over, hvad der van Rum til. Lnder dyb Stilhed begyndte Monrad at tale fra sin Plads averst $i_{1}$ Salen ved det korte Ministerbord nærmest Vinduerne, og , den diskante, læspende Stemme lød tydeligt hen under den høje, bredt facetterede Tondehvælving. Han talte usandt og sandt ind imellem hinanden i vel overvejet Blanding. Den umiddelbart, sandfaerdige .Fremstilling af sin Viden om Sagens Sammenhæng havde han opgivet, med den vilde han her lige som nys blandt Kollegerne kun komme til kort:

wMine Herrer, jeg kan af det Indtryk, som, $Q p g i_{-}$ yelsen af Danevirkestillingen har gjor paa mig selv, lot forklare mig det Indtryk, den maa have gjort saq Yel paa de, ærede Herrer Medlemmer af Rigsdagen som paa Københavns Borgere i Almindelighed 4 .... "Jeg ser mig ikke i Stand til at give Dem en Forkla- 
ring af, hvad der har bevæget Krigsraadet til med 10 Stemmer mod 1 at beslutte Opgivelsen af Danevirkestillingen".... "Det er mig uforklarligt, og jeg ser mig som sagt ikke i Stand til derom at meddele nogen Oplysning".... "Denne Efterretning kom som et Tordenslag ikke mindre paa Als [hvor Kongen og Taleren opholdt sig] end i Kobenhavn“.... "To Hensyn havde den kommanderende General at tage, det ene: at han havde at yde et alvorligt, Nationen værdigt, Forsvar af Danevirkestillingen, det andet: at Arméen ikke blev oprevet ved dette Forsvar. Hvad der nu har gjort, at Sagen har stillet sig saaledes for ham, at han til det paagældende Tidspunkt har troet at burde forlade Stillingen, det er det, som ikke ligger klart for. Der er ingen her, som derom ved Besked, da, som sagt, det Aktstykke [Krigsraadsprotokollen] mangler, der skal indeholde de fornødne Oplysninger i Sagen. Jeg kan derfor ikke andet end aldeles billige, at min højt agtede Kollega [Krigsministeren] har besluttet at hidkalde den kommanderende General og Stabschefen for at afæske dem en Forklaring“ .... „Et Punkt er der desuden, som særligt maa opfordre til at hidkalde den kommanderende General ... det nemlig: at hans Beslutning om at forlade Danevirkestillingen er tagen, uden at han derom forud har henvendt sig til Krigsministeren«.... »Jeg vilde finde det naturligt, at selve Krigsministeren, dersom det paa nogen Maade var muligt, ikke vilde have taget en saa skæbnesvanger Beslutning uden derpaa at have erholdt allerhøjeste Approbation. Der har, saa synes det, dertil været tilstrækkelig Tid.» 
Her fik Monrad den første egentlige Tilslutning fra Medlemmerne og Tilhørerne, hvilke sidste trods Formandens Advarsel livligt havde grebet ind, og til hvem Monrad havde henvendt sig nok saa meget som til Folketingsmændene. Hidtil havde han med sine mange Ord, der alle havde været beregnede paa at stille ham og Kongen paa lige Fod med de over for Opgivelsen af Danevirkestillingen uforberedte Rigsdagsmænd og Kobenhavnere, talt til en afgjort fjendtlig Forsamling.

»Men lad os ikke dømme overilet!« fortsatte han og løftede Stemmen som frigjort fra et moralsk Tryk. "Besindigheden dømmer ikke, før Sagen er oplyst fra alle Sider. Da jeg talte med den kommanderende General, Stabschefen og dem, som staar disse nærmest, beundrede jeg dem. Der var over dem udbredt den største Koldblodighed og Rolighed, stottet paa Overbevisningen om, at en alvorlig Modstand maatte gøres ved Danevirke. Lad os derfor ikke letsindigt gaa hen og fordømme saadanne Mænd«. Raab og vrede Protester styrtede her som et pludseligt Uvejr ind over Taleren fra Tinget og fra Tilhørerpladserne. Monrad gjorde et Skridt frem, og hans Stemme skar gennem den Rest af Larmen, der nu lige som løb tilbage mod sit Udgangspunkt: "Ja, vil De, mine Herrer, letsindigt gøre det, bliver det Deres Sag, jeg vil det ikke! «

Monrad havde i Brøkdelen af et Sekund faaet lagt det Ansvar for letsindig Dommen over paa Tilhørerne, som disse ved deres Raab netop vilde fri sig for, og opnaaet at tage Afstand derfra, og styrket ved Følelsen af, at det var lykkedes ham, vedblev 
han; pJeg vil sige Dem en Ting. Et.Tegn paa, at en Nation er sin Oplasning nær, det er, naar man slynger Ordet: worraderik ud imod dem, som.tjener de res Fædreland tro naar man kaster. Mistanke paa dem, som er beredte. til at ofre denes Liv for Fædres landet, naan der, medens Fjenden staar i Landet, og Kanontordenen høres fra den ene By!til den anden, laves Gardeoplob og Tumulter, hvorved man tror at tiltvinge sig visse Beslutninger, og som gor det nodvendigt med Magt at værne om den offentlige Orden og Kongehusets Sikkerhed火.

Taleren havde. nui tydelig besejret Uroen i Salen, og fra nu af lød hans Røst som fra et Stade, omgivet af Højsædestøtter; *Mine Herrer, jeg ved, at et stort Ansvar hyiler paa mig. Ikke har jeg bævet tilbage for at bære dette Ansvar, og jeg siger derfor: Havde jeg Skygge af Ansvar med Hensyn til den tagne Krigsraadsbeslutning om at forlade Danevirkestillingen, sandelig, jeg skulde staa frem og skulde -ikke frygte. Skriget imod mig. Men det,beder jeg ${ }_{1} \mathrm{Dem}$ om, og jeg anraaber i den Henseende peres Retfærdighedsfølelse, at naar Mænd, som har vist sig modige og kække $i$ mange Feltslag .... tager en Beslutning, som De, mine Herrer, ikke kan forkkare Dem, at De da ikke lader Mistanken, falde paa dem, før deres Adfard er oplyst, og deres Bevaggrunde lig ger klart for, - og for Gud i Himlens Skyld, lad det ikke komme dertil, at Bevægelser paa Gaderne skulde være det, der udøvede Indflydelse paa Regexingens Beslutninger!*

Folketingssalen var i Ministerens Magt, og Monrad benytteqde Lejligheden til at słutte af med kprt at erklære, at lige saa lidt som han vilde vige for Gade- 
bevægelser, lige saa rede var han til at vige som Konsejlspræsident, hvis Repræsentationen ytrede Ønske derom. Denne Erklæring gentog han kort ef ter i Landstinget, da han der gav en lignende Fremstilling af sit Forhold ved Danevirke som i Folketinget.

Begge Rigsdagens Afdelinger vedtog saa en for Mødet redigeret $\downarrow$ Henvendelse til Nationen om, at denne trostig kunde forlade sig paa Rigsdagens Vilje til af'Regeringen at krave det kraftigst muligé Forsvar for Landets Are og Selvstændighed, og Monrad, der lige saa'lidt nu sorn i Reglen ellers, selv i afgørende Øjeblikke, følte Trang til nært personligt Samkvem med hogen af dem, han i det offentlige Liv stod sammen thed, skyndte sig bort frá de mange Mennesker, der fyldte Rigsdagskorridorerne og ae tilstødende Opholdsværelser, nd i Amaliegade til det gule Palæ, for at forsikre Dronningen, at hun ikke behovede at frygte nye Forulempelser ${ }^{2}$ ) eller for en Gentagelse af Urolighederne fra den foregaaende Aften, han havde sørget for betryggende Foranstaltninger i saa Henseende. Dronningen, som àlt var vel underrettet om, hvem der i Virkeligheden sørgede for dette, svarede ikke uden Malice, at hun ikke nærede Frygt af nogen Art, men at Hs. Højærværdighed

1) Ved Bortkorslen fra Gudstjenesten i Frue Kirke samme Sundag Formiddag var den Vogn, hvori Dronning Louise sad med sine unge Dotre, Prinsesserne Dagmar og Thyra (senere henholdsvis Kejserinde af Rusland og Hertuginde af Cumberland), blevet omringet af den sammenstimlende Mangde, som raabte \$kældsord ind gennem de aabne Vognvinduer, og en Student (senere Præst i Nardsjalland) spyttede ind i Vognen, hvorved han ramte Pripsesse Dagmar. IL. T. 8 R. V, 80 . 
selv vist havde Grund til at være forberedt paa et og andet fra Befolkningens Side ${ }^{1}$ ). Monrad tog sig dog ikke denne Advarsel nær. Han begav sig til sin Bolig paa Christianshavn, og træt af de sidste Døgns Anstrengelser gik han tidlig til $\mathrm{Ro}^{2}$ ).

I sin Bog om Monrad fortæller Frederik Nørgaard, i Overensstemmelse med, hvad Sofus Høgsbro har meddelt ${ }^{3}$ ), dog muligvis hentet fra anden Kilde, at Monrad bestandig senere regnede Søndag 7. Febr. 186 if "for en af de bedste Dage i sit Liv«, da han "sjælden havde folt en saadan Magt $i$ sine Ord som den Dag «, og Sagen er trolig nok, uagtet man kunde synes, at den lidet glædelige Anledning kunde skygge over Monrads Behag ved at mindes sine Ords Magt hin Dag. Men han havde jo følt sin politiske Tilværelse truet. Han havde haft Valget mellem at

1) Marcus Rubin: Nogle Erindringer 39.

2) En Tradition om, at Monrad hin Aften efter at være kommen ud i Brogade paa Christianshavn lod Kinippelsbro trække op hag sig, har det at støtte sig til, at Broen den Aften ved Politiets Foranstaltning en vis Tid har varet optrukket, ved hvilken Lejlighed den led Overlast af den ved de loftede Broklapper standsede Mængde.

Politirapporten fra Christianshavns Station Mandag 1864, 8./2. lyder saaledes: Broopsynsmand Beck boende $i$ Brogade Nr. 1:2, der har Opsyn med Knippelshro, anmeldte Dags Middag paa stationen, at der i Gaar Aftes ved den Folkestimmel, der fandt Sted paa Broen, efter at Politiet havde requireret Broen ophejset, ved denne Lejlighed er bleven itubrukken 3 Jernstænger og 2 Broklapper, som formentlig er kastet i Vandet efter at vare itubrukne, hvorfor den afstedkomne skade, efter at være istandgjort, fordres af Politiet erstattet. Gigtved, Fung. Overbetjent 55\%. Ved "Broklapper" maa dog her vistnok forstaas noget andet og mindre end det, man i Almindelighed forstaar ved Knippelsbros Broklapper. Det kobenhavnske Politis Arkiv.

3) Sofus Higsbro 1. c. 40. Fr. Norgaard: D. G. Monrad 173. 
følge den snævre Sandhedens Sti, som han var kommen ind paa $i$ Kongens Omgivelser, og som førte brat ned fra det lllusionernes Højdedrag, der med ét Ord hed Danevirke, og hvis Egenart det rimeligvis forgæves - og i saa Tilfælde til Ødelæggelse for ham i Nutid og Fremtid - vilde koste ham hans sent vundne Indsigts yderste Evne at prøve paa at faa Folk til at begribe, og i Modsætning dertil at føre disse samme Folk uden om i de Benægtelsernes side Enge, hvorfra Udsigten til Højdedragets Eventyrdis i det væsentlige forblev uanfægtet, men hvor ganske vist den Mangel klæbede ved Maalet, man naaede, at Ret der var bleven til Uret, og han valgte det sidste, for nu gjaldt det blot om, at $\mathrm{h}$ a $\mathrm{n}$ var uovervunden. Det var til hans Person, at Sandheden i denne Sag var fæstet, det skulde Konge og Fædreland nok erfare!

Da han efter Møderne i Rigsdagen atter følte sig sikker i sin Stilling, var det, han sidst huskede: den blutale Omstændighed, at han virkelig havde været stillet overfor Valget mellem sandt og usandt, og havde hjulpet sig igennem med det sidste. Forøvrigt maatte nu General Meza benytte den Lejlighed, der blev givet ham, til at vende Stemningen om til Gunst for sig.

Ud paa Aftenen kom der til Brogade paa Christianshavn dragende over Langebro en Hoben Mennesker, og under Monrads Sovekammervinduer, der paa forste Sal vendte mod Gaden, gav de sig til at raabe: "Ned med Forræderen!" "Hvad fik Du for at lade Kanonerne fornagle? . "Til Helvede med din sorte Sjæl!« og andet af samme Slags, og Ministeren der var bleven vækket af Støjen, rejste sig lyttende i 
Sengen og tænkte med en vis undrende Tilfredsstillelse paa, hvor fvrigt selv Gadens Folk i Kobenhavn fulgte med 1 de nationale 'Begivenheder, og hvilken kostbar Sum af noralsk Folelse der her, rigtig an vendt, var at regne' 'med ved Arbejdę for Landets Fremtid: Han kastede len 'Slobrok om sig, og i det abbnede Vindue iagttog hán den raabende Mængde ${ }^{4} \%$, der for ovrigt snart blev ked af Situationen, og da nogle Politibetjente kom til, let lod sig fordrive.

Da han om Tirsdagen efter denne Sondag atter stod i Folketinget, og det i Mellemtiden for alles Øjne sort par hvidt $\rightarrow$ blandt andre Steder'f Dalgbladet $\leftarrow$ var blevet godtgjort, at der gabede en adbenbar Modsigelse mellem hans Omtale 1 Rigsdagen af Danevirt kestillingens Opgivelse og de af ham i Anledning af denne Begivenhed forfattede Kongeord til Soldaterne, idet i Proklamationen Grunden til Tilbagetoget kort og godt og tydeligt nok var angivet som den truende Tilintetgørelse af Hæren, og i Rigsdagen Begivenheden var blevet betegnet af ham som ham uforklarligh, gjorde dette saa lidet Indtryk paa den nu for en Tid sindsligevægtige Momrad, at han i sit Svar dels kunde give sig Ro tìl at faa anbragt en rammende Spot over sine Modstandere; dels kunde benytte til Forklaring en saa vovet Omstilling af Forholdene,' at han kun kunde vente at faa den anerkendt som god, saa længe man i det hele undlod at tænke Sagen igennem:

Ganske vist, sagde han, havde han i Proklamationen kunnet anforie Grunden til, at Hæren var gaaet tilbage fra sin Stilling ved Danevirke, for der

1) Se foruden Monrads Udtalelser i Folketinget 1864 9. 2. . en Notits i Politiken 1914 24./1. 
stod i de Meza's Instruks, at Forsvaret af Stillingen ikke maatte fore til, at Hæren blev oprevet, altsaa, naar Tilbagetoget var tiltraadt, kunde Grunden kun [!] være, at Armeen ellers vilde vare blevet tilintetgjort, [Hvilken Tillidserklæring til de Meza!] og denne Aarsag kunde han derfor rolig anfore [Hvorfor næevnede han den da ikke i Rigsdagen?]. Men naar man deraf vilde udlede, at der for ham ikke var noget uforklarligt $i$, at Danevirke var bleven forladt, maatte han gøre opmærksom paa, at det, der trængte »til Forklaring, tîl nærmere Oplysning«, var, "at man [Overkommandoen] on Onsdagen ikk troede, at Omstændighoderne var saaledes, at Stillingen burde opgives, og at man 24 Timer efter kom til den modsatte Overbevisning «.

Nej! Dette i og for sig ikke sarlig vanskeligt forklarlige og forovrigt her skævt fremstillede Faktum var ikke det, man om Sondagen i København fordrede Forklaring paa - , det vidste Montad, og det vidste hans for to Dage siden saa farlige men nu saa medgørlige Tilhørere godt. Men over for den Dristighed, hvormed han fremforte denne Tilsnigelse, veg Tilhorernes Viden til Side som en Taagebanke for et Vindstod, og i den derved frembragte Tomhed i Forestillingerne tabte sig Erindringsbilledet om, at det, man om Sondagen med saa stærk Vilje havde forlangt at forstaa, var udelukkende, hvordan det var muligt, at rogen dansk kommanderende uden Forræderi havde kunnet forlade Danevirke, saalænge blot en eneste Kanon jér endinu kunde bære mod Fjenden, og ikke den af Monrad nu fremdragne, af Tilhørerne ikke tidligere kendte, Biomstændighed ved den store Svigten, at der tilsyneladende havde været en Vaklen $\mathbf{i}$ Be- 
slutningen. Monrads hallucinerende Evne over sine Tilhørerer var atter traadt i Virksomhed.

Foruden denne Tilhørernes Tankeforbløffelse, der altsaa her fulgte med hans Ord, og som mærkeligt nok holdt sig ogsaa efter at Ordene forelaa trykte $i$ Rigsdagstidende, havde imidlertid nogle af ham $i$ 'Tirsdagsmødet fremsatte fuldkommen rigtige og selvindlysende Redegørelser bevirket, at man ikke nu og ikke nogensinde senere gik ham nærmere paa Klingen i Anledning af Modsigelserne i hans Forklaringer med Hensyn til Danevirkespørgsmaalet. Mistanken mod ham og Kongen for at have spillet under Dække med forræderiske Personer i Armékommandoen havde han paa de afgørende Steder faaet fjernet - i Periferien kunde man møde den endnu længe efter ${ }^{1}$, -, og dermed bortfaldt Interessen for Spørgsmaalet om hans Forudviden angaaende Tilbagetoget.

Konsejlspræsidenten var paany en Personlighed, man skyldte Respekt, der kom endog en Tilsætning af Varme i de Følelser, hvormed man nu i Rigsdagen hørte paa ham efter de urigtig anbragte Beskyldninger for Forræderi, han havde været Genstand for, og Monrad mærkede det. Han havde straks benyttet sig af den for ham gunstige Luftning, der gik gennem Folketingssalen, og havde spottende holdt frem til Beskuen de "Ledere af den offentlige Mening « - Re-

1) Fru Julie Winther, Christian Winthers Hustru og Monrads Svigerinde, skriver t. Eks. 1865 27./4. til Carl Snoilsky, at hun véd med Vished, "at vi ved Danevirke blev forraadt", Prøjserne havde lovet, at blev blot vore Tropper trukket tilbage, skulde Kongen faa Holsten og Slesvig i Personalunion. Det var dog "det konge- og adelige Parti«, som her skulde have været paa Spil, ikke Monrad. Carl Snoilsky och hans Vänner I, 179-180. 
daktørerne Bille og Ploug, Medlemmer henholdsvis af Folketinget og Landstinget -, der i deres Avisartikler i Dagbladet og Fædrelandet med en Voldsomhed uden Lige og en forstokket Blindhed, som fornægtede alt Ansvar, havde hidset Stemningen i Kobenhavn op saa vel mod Monrad som mod Kongen og Generalerne for derpaa, da Gadetumulterne tog fat, at mane til Ro: »Det fremkalder næsten et Smil hos mig," sagde han, "naar jeg tænker paa deres Adfærd, thi der fremstiller sig for mig Billedet af, at man holder en tændt Lunte til en Krudttønde og da siger: Spring ikke, lille Krudttønde, thi det gør stor Skade, om Du springer«.

Det var dette muntert lydende Svar paa de fanatiske Angreb mod ham, som Datiden mest holdt sig til, naar Talen kom paa Monrads Optræeden efter Danevirkedagen, og blandt andet for dette Svars Skyld glemte man at lægge Mærke til, at nogenlunde den samme Fremgangsmaade, som han paaviste hos sine Modstandere, benyttede han selv overfor de Meza, ganske vist ikke i Blinde og i Ophidselse, men i den bestemte Hensigt, som lykkedes, at vinde Indgang hos de mod de Meza og ham forud indtagne Iagttagere. Først fremstillede han (mod bedre Viden, det er en Sag for sig) Generalens Handlemaade ved Danevirke som værdig til at fremkalde dennes øjeblikkelige, om end naturligvis til en Begyndelse foreløbige, Fjernelse fra Overkommandoen og til Krigsministerens nøje Undersøgelse, og derpaa udbryder han: Men lad os ikke letsindigt gaa hen og fordømme en saadan Mand! Og da der opstaar Uro i Forsamlingen, hvad Jesuitismen i Ministerens Ord ikke er uden Skyld i, svinger han sig op til en efterhaanden næsten 
serafisk Højde, hvorfra.han ikke stiger ned, før han kan gøre det som Sejrherre først over sin egen $\mathrm{Be}+$ skæmmelse ved den anvendte Usandfærdighed og dernæst over Stemningen-i Forsamlingen. ।

Monrad var kommen frelst gennem Danevirkedagenes Brænding. Der var imidlertid det pinlige Sporgsmaal om General Meza og Oberst Kauffmann tilbage. Værre dog end denne Anledning til moralske Sting virkede paa ham Tanken om hans Forhold til Kongen. Majestæten havde ifølge sin Natur og sine øvrige Forudsætninger ikke megen Mulighed for at forstaa Tilladeligheden af en af politiske Grunde foretagen større Omgaaen af Sandheden, denne altsaa opfattet rent borgerligt. For hvor var i denne Forbindelse, ret beset, Sandheden at søge? Og i det foreliggende Tilfælde vilde det blive saa meget sværere at bibringe ham denne Forstaaelse, som den af hans Minister valgte Udvej bort fra Vanskelighederne forte i stik modsat Retning af den, hvori hans Vilje gik. Han var jo i alt for ringe Grad tilbøjelig til at tage Hensyn til den Fare, der i selve Hjemlandet truede hans Dynasti, men som Forsteministeren uafladelig maatte have for $\emptyset_{j} \mathrm{i}$ sine Beslutninger.

Monrad saa dog intet Middel til, hverken aabenlyst eller under Haanden, at forandre sin og Ministeriets Holdning i denne Sag. De Røster, der ude i Folket blandt mere eller mindre sagkyndige havde hævet sig til Forsvar for det frivillige Tilbagetog fra Danevirkelinjen, og som fra lignende Hold kunde formodes fremdeles at ville blive rettet imod den opfanatiserede Folkestemning, var for svage til, at et Ministeriums Chef derpaa kunde bygge noget som helst, 
hivor megen Ret og Rigtighed de end forkyndte. Krigsministerens Vrede faldt sammen med Nationens Vilje og maatte - i alt Fald forelobig - blive Rettesnoren for Regeringens indre Politik.

Men alt vel overvejet, hvor meget hellere vilde han mu ikke i al Naturlighed have udnyttet det Klarsyn, han mente at have vundet, da ban med Oberst Kauffmanns Haand i sin stod paa Flensborg Gade. Havde han ikke da følt en velgørende Ro ved Forestillingen om, at den blinde og derfor ofte vaklende Forsynstro i rent menneskelige Ting, i Farens Stund burde vige Pladsen for Tilliden til den Hjælp, der var at finde $\mathbf{i}$ erfarne Mænds rolige Beslutningsevne? Havde han kunnet holde sig alene til denne Oplevelse, vilde han først og fremmest nu have opnaaet den personlige Tilfredsstillelse at holde det oppe, som han umiddelbart ansaa for det rette, og dernæst vilde Kongens Gunst have været ham sikkert bevaret. Som Forholdene imidlertid havde stillet sig, maatte han imødese Kongens Tilbagekomst til København 10. Febr. med en Spæending, der var ham højlig imod. Den var langt under hans Værdighed, han, der for blot at mindes det sidste, for nogle Dage siden Ansigt til Ansigt med Folkets udvalgte let havde hrevdet sin Overlegenhed.

Ved Mødet med Kristian 9. om Onsdagen 10. Febr. blev derfor de yderst forbeholdne Miner, der bag den officielle Høflighed vistes ham, hos ham, kun for Luft at regne, og efter en kort Ordveksel fik han det formelle Samtykke til Afholdelsen af det Statsraad, han havde indkaldt til næeste Dag. Intet tydede paa Modstand fra Majestætens Side mod hans storpoli- 
tiske Planer, der nu udelukkende kunde gaa i krigersk Retning.

I dette Statsraad 11. Febr. foreslog altsaa Monrad i Overensstemmelse med de af Folketinget og Landstinget Søndag 7. Febr. vedtagne Beslutninger, at whele Landets og Folkets Kraft skulde opbydes for at [det kunde] fortsatte Krigen og efter bedste Evne værge sig mod Tysklands Voldshandling«, og Forslaget var saa hurtig vedtaget som fremsat. Men mærkeligt nok, den Vedtægt, som bød, at hvad der foregik i et Statsraad, skulde i Indlandet, indtil andet bestemtes, forblive "geheimt« - med Hensyn til Udlandet forholdt man sig efter Lejlighed anderledes $\left.{ }^{1}\right)-$, blev foreløbig ikke brudt. Monrad havde dog udtrykkelig formet sit Forslag med Tanken ikke alene paa selve det Anliggende, dether drejede sig om, og paa Danmarks Stilling i Europa, men ogsaa paa det Indtr'yk, Beslutningen vilde gøre i Landets krigersk stemte offentlige Mening. Den sejglivede Mistro til ham og Kongen angaaende deres Forhold til Krigsforelsen skulde forsvinde! Og det varede dog en halv Snes Dage, inden Folk, tilmed ved en tilfældig fremkaldt Oplysning $\mathrm{i}$ Berlingske Tidende, fik positivt at vide, hvad der i Statsraadet var blevet besluttet ${ }^{2}$ ). Paa anden Haand havde man naturligvis $i$ de mere eller mindre indviede Kredse faaet tilstrækkelig Underretning.

Men hvor alvorligt Monrad end følte Beslutningen om, at Krigen skulde med ham i Spidsen for

1) Ved denne Lejlighed gav Monrad ojeblikkelig den svenske Gesandt i Kobenhavn, Grev Hamilton, Underretning om den fattede Beslutning. H. Hamiltons Brefsamling II, 144.

$\left.{ }^{2}\right)$ Berlingske Tidende Aftenudgave $186420 . / 2$. 
Nationen føres, om nødvendigt, med Benyttelse til det yderste af Landets samlede Kræfter, gik det hverken ved denne Lejlighed eller senere under Krigen op for ham, at uden umiddelbar Samvirken mellem ham som Leder og Nationen som ledet lod dette sig ikke udføre. Monrad havde i Januar talt til de fremmede Gesandter og Udsendinge i København om at "rejse Folket« - lancer le pleuple ${ }^{1}$ ) -, men aldrig forekom der $\mathbf{i}$ hans Ministertid blot et Forsøg fra hans Side paa at virkeliggøre en saadan Plan.

Han forblev i sin officielle Ministerham som den af Kongen kaldede. Han var selvfølgelig tilgængelig for sine Kolleger, men søgte sjældent dem, talte derimod ofte og gerne med de fremmede Gesandter $i$ København og nu og da med enkelte foretrukne indenlandske Raadgivere som Tscherning, Andræ eller Balthazar Christensen og passede uden at trættes, indtil den sidste Smaating, de tre eller fire Ministerier, som til forskellige Tider, dog med fremragende Hjælp, var ham underlagt - i Finansministeriet var C. E. Fenger, i Udenrigsministeriet P. Vedel Direktører. Han var tidlig og sent hos Kongen med Beretninger om alt muligt, førte Forsædet i Ministerraad, forhandlede med Rigsdagen og dens Udvalg, senere med Rigsraadet, og enkeltvis med Medlemmer af disse Forsamlinger og talrige udenforstaaende, gav villig Audiens og traf nu som før et Utal af Afgørelser. Han tumlede bestandig med Planer angaaende Landets største Anliggender, stundom ogsaa angaaende Landets mindste, men naar undtages den hastig fattede og gennemførte Beslutning Søndag 7. Febr. om Mødet med Repræsentanter for Københavns

1) Neergaard II, 986. 
Borgere'og Landets Akademier var enhver Tanke om at træde $i$ umiddelbar. Forbindelse med Nationen som saadan ham fjærn. End ikke Pressen benyttece ban, skønt det havde ligget nær for ham som gammel Journalist at have husket dens Betydning. Særlig if Slesvig og Sydjylland var der Længsel efter at faa Ord fra den høje Regering at høre, Monrad tænkter ikke derpaa $\left.{ }^{1}\right)$. Med al ain (Handlekraft var han Konsejlspræsident, dernæst Finansminister og Udenrigsminister osv., men udenfor denne Ramme traadte han ikke.

Forøvrigt var det Beslag, der nu efter Regeringens højtidelige Beslutning skulde lægges paa Landets og Folkets Kraft, for en almindelig Borger vanskeligt at spore. Hæren var, tildels mangelfuldt udrustet - det kom hurtigt op, at den blandt meget andet manglede baade Heste og Transportmidler -., forlangst sendt i Felten, men paa Kobenhavns Gader og $\mathrm{i}$ andre Garnisonsbyer gik der Tusinder af halvuniformerede Forstærkningsmænd og drev,jikke at tale om, at Garden blev i Hovedstaden og trak paa Vagt som sædvanlig. Af Rigsraadet var der i December 1863 bevilget ialt 30 Millioner Kroner, der var en nsvæevende" Statsgæld paa omkring 12 Millioner Kroner, og nu var der i Bigsdagen forelagt et Lovforslag om en saare skaansom Krigsskat, der var vedtaget et lille Tillæg til den lave Spiritusber skatning, og der bebudedes forlods Indkaldelse af

7) I mationale Kredse savnede man vejledende og stattende Opraab fra Statsstyrelsen til de mange i Slesvig, som under den fjendtlige Besattelse af Landet onskede uden alt for stor personlig Ulempe at vise derés mod Danmark trofaste Sindelag. 
næste Aars værnepligtige. Man var i Krigsministeriet optaget af at skaffe sig det uomgængeligt nødvendige fra Haanden, uden at Tempoet var sat væsentlig op. Krigsministeren formaaede ikke - som Monrad senere klagende har udtrykt det - at "gøre Nat til Dag ¿ $^{\mathrm{P}}$ ), og i Marinen var efter Tidens Vilkaar "hurtig Udrykning « et ukendt Begreb, hvad forøvrigt Aarstiden ogsaa vanskeliggjorde. Folket passede sit Arbejde og sine Fornøjelser, man læste sine Aviser og samlede villigt ind Penge og alle Slags Fornødenheder til Soldaterne og lod saa den væbnede Magt og dem, der stod for Styret, om at rogte Krigens Opgaver, medens dog $\mathbf{i}$ visse Egne af Jylland de enkelte Husstande gjorde sig rede til at tage mod Fjendens Besøg. Yderligere skete der intet. Heldigvis syntes Fjenden foreløbig heller ikke at have travlt.

12. Febr. lod Quaade saa udgaa til Danmarks diplomatiske Agenter i Udlandet en Depeche, som klart angav Grundene til, at den danske Hær havde forladt Danevirkestillingen for at besætte Forsvarslinjen ved Dybbøl: Aarstidens overordentlige Strænghed, de uophørlige Nattevagter og Troppernes store Udmattelse, sammenholdt med Fjendens betydelige Overmagt, havde nødvendiggjort Bevægelsen. Nu stod Hæren i Fjendens Flanke bag en befæstet Linje, der ved $\sin$ Beliggenhed ved Havet forenede alle de Fordele, som Landets geografiske Forhold tilstedede, og Krigen vilde blive ført saa længe, indtil Tingenes tidligere Stilling var blevet genoprettet.

Den oprindelige Overkommandos Opfattelse af Forholdene var umiskendelig i den første Del af

1) D. G. Monrad: Politiske Breve Nr. 1-4, 82. 
denne Depeche, som Monrad efter Aftale tog imod fra Quaade, som den bodes ham: den var med den aabenbare Blotstillelse af Krigsministerens Optræden overfor General Meza heldigvis ikke beregnet paa at komme til de øvrige Ministres eller til Offentlighedens. Kundskab - foreløbig. Og ligesom disse Oplysninger var rigtig affattede til Brug i Ldalandet, var de $\mathbf{i}$ Overensstemmelse med hans eget Forsøg paa Forklaring af Tilbagetoget i Ministermødet 7. Febr., hvilket altsaa ikke kunde og ikke skulde tilsløres under Samtalerne med Quaade, bag hvem desuden den i dette Spørgsmaal saa nøjeregnende Konge stod. Man fik saa se, hvad der senere i denne Sag skulde ske.

- General de Meza, der sammen med Stabschefen, Oberst Kauffmann, var kommen til København Dagen før Kongen, indsendte efter Ordre til Krigsministeren 15. Febr. sin Redegørelse for, hvad der havde bevæget ham til at befale Danevirkestillingens Opgivelse, og Redegørelsen endte med følgende Ord: "Jeg havde derfor.... kun Valget mellem enten at tiltræde en frivillig ved strategiske Grunde motiveret Tilbagegang eller, med ringe Udsigt til endnu i faa Dage at modstaa Fjendens Angreb, at blive tvungen til en Retrate, hvis Folger var uberegnelige, og som efter min Anskuelse maatte føre til Hærens Opløsning og Tilintetgørelse. Jeg valgte det første og venter for min Beslutning Armeens, Landets og Regeringens Tak, saa snart de meget naturlige smertelige Forestillinger og Følelser, med hvilke Landets gamle og eneste Grænseværn ses overladt i Fjendens Vold, har indrommet den rolige Betragtning af Forholdene den Plads, som den under Landets alvorsfulde Situation har Krav paa«. Og Krigsministeren 
blev han ikke mere velsindet, end han i Forvejen var, ved denne Tiltale fra oven nedad.

Men endnu mindre fandt Ministeren Behag $i$ de Bemærkninger, hvormed de Meza afsluttede denne Del af sin Skrivelse: "Deres Ekscellence vil erkende, at det under de givne Omstændigheder ej heller var tilraadeligt at indhente Krigsministeriets eller Regeringens Bemyndigelse.... Det besluttede Skridt laa indenfor den mig med Armeens Overkommando anbetroede Myndighed, og jeg kunde hverken ønske, at Usikkerhed og Vaklen indtraadte under Uidførelsen deraf, eller tragte efter selv at afkaste og saaledes at overlade Ministeriet et Ansvar, som min Overbevisning gav mig Ret, Mod og Kraft til at bære«. $\left.{ }^{1}\right)$ Dette stolte Sprog kunde mulig, selv under de for Haanden værende Forhold, hos Monrad have fundet den Forstaaelse, det paa en Maade forudsatte, men til den aandelig saa meget snævrere anlagte Lundbye passede det ikke. Han erklærede sig i en Skrivelse af 18. Februar for utilfredsstillet særlig netop ned Forklaringen af Aarsagen til, at han ikke umiddelbart efter Krigsraadets Afholdelse havde faaet Melding om den fattede Beslutning, og krævede nye Oplysninger. Disse fik han delvis i et Svar af 20. Febr., som baade i Realiteten var indgaaende og i Tonen afvisende. $\left.{ }^{2}\right)$

Dagen før havde Lundbye sendt den fungerende Overgeneral Lüttichau den meget uvelkomne Ordre, der imidlertid til Trods for Generalens Protest maatte lystres, at nedsætte af Herens Personale tre Kommissioner, der skulde undersoge »den [af de Meza i sin

1) Generalstaben: Den dansk-tyske Krig 1864 I, Bilag $109-116$.

2) Sammesteds 116-117, 118-122. 
Redegørelse] paastaaede mangelfulde Tilstand, hvor: Armeen havde befundet sig, og allerede 4 Dage efter Fjendtlighedernes Udbrud«, hvilke Kommissioner. var tænkt som Midler til at skaffe Materiale til Veje imod de Meza, men hvis Undersøgelse hurtig formede sig som en Anklageakt imod Ministeriet for den Maade, hvorpaa dette havde forberedt Felttoget ${ }^{1}$ ).

Men samme Dag som de Meza havde afgivet sin sidste Skrivelse til Krigsministeren, sendte han denne et Brev, der blev Begyndelsen til Enden paa Striden mellem disse to og ulykkeligvis samtidig Udgangspunktet for den nedadgaaende Linje, som Krigsbegivenhedernes Kurve i 1864 beskrev paa vor Histories Tavle. I dette Brev udtalte de Meza Forventningen om nu efter de fyldestgørende Forklaringer, han havde indleveret, at modtage Regeringens Tilkendegivelse af hans "Handlemaades fuldkomne Berettigelse og Betimelighed" og Ordre til "som snarest" med sin Stabschef at vende tilbage til Armeen for paany at overtage Overkommandoen: i modsat Fald forbeholdt han sig "som Erespligt og i Sandhedens Interesse at offentliggøre de mellem Ministeren og ham vekslede Skrivelser. ${ }^{2}$ )

Forholdene maatte i Sandhed være vredne stærkt af Led, for at den ellers under alle Hændelser rolige General kunde forglemme sig i den Grad, at han kunde true sin Minister med eventuelt at overgive til offentligheden tjenstlige Dokumenter, men Tilstanden var ogsaa ret utaalelig for den i høj Grad ærekære de Meza. Han var vedblivende i den Presse, som bestemte

1) P. N. Nieuwenheus: Krigsproblemet 340 og Rigsraadstidende 1864 Tillæg B. Sp. 147-320.

2) Generalstaben: Den dansk-tyske Krig 18144 I, Bilag. 
den offentlige Mening i Danmark, foruden i saa godt som alle indflydelsesrige Kredse uden for Hæren og Hoffet, Genstand for ondartede Angreb, der i Kraft af disse Modstanderes Uvidenhed om Sagens virkel:ge Sammenhæng fik Præg af næsten barok Perfidi, og Krigsministeren syntes besluttet paa, hvad der end kom til at foreligge, og uden Hensyn til de skadelige Virkninger af en midlertidig Besættelse af Overkommandoen, at trække Afgørelsen i Langdrag, saa at Generalen ikke, mens det var Tid, kunde faa Oprejsning for den Tort, der var overgaaet ham. Og pint mere end nogen vidste, begik han da den store taktiske Fejl, som hans Modstander ikke var sen til at benytte.

22. Febr. indsendte Lundbye til Kongen de Meza's afsluttende Brev med en Skrivelse, hvori han meddelte Majestæten, at uanset, hvordan Undersøgelsen angaaende Tilbagetoget faldt ud, maatte han betragte det som umuligt at genindsætte i Overkommandoen en Mand, der optraadte overfor Krigsministeren paa den i Brevet angivne Maade, og at der derfor næste Dag fra Krigsministeriet vilde udgaa Bestemmelsen om, at de Meza endelig skulde fratræde sin Post.

Men her begik Krigsministeren paa sin Side $i$ sin Forhippelse efter at drage Fordel af det Overtag, han havde faaet, et Fejlgreb, som kunde have fældet ham, hvis han ikke i rette Tid havde faaet Hjælp. Kongen var paa ingen Maade til Sinds at finde sig i den Tilsidesættelse, der laa $i$ her af Krigsministeren at blive berøvet den afgørende Stemme, og umiddelbart efter Modtagelsen af den krigsministerielle Skrivelse udbad han sig af Ministeren skriftlig fornøden Forestilling i Sagen. Da denne saa Dagen ef- 
ter allerunderdanigst blev indgivet, forlangte Majestæten fyldigere Oplysninger, samtidig med at han paalagde Krigsministeren i Kongens Navn at tilkendegive Generalen, at han havde fejlet ved at udtale sig over for sin Minister som sket var.

Kongen vilde ikke lade de Meza falde. Generalen havde for det forste ubetinget Ret i den for Krigens videre Førelse saa afgørende Beslutning, han havde taget, hvad Kongen umiddelbart efter Begivenheden jo havde tilkendegivet ham som sin - det vilde for Majestætens private Forestilling sige: den egentlige Krigsherres ${ }^{1}$ ) - Mening, de Meza liavde dernæst samtlige højere kommanderendes Tillid, og han havde vist, at han foruden det strategiske Overblik og det store Soldatermod besad den sjældne Egenskab, til Trods for sin maaske endog sygelige Erekærhed, ikke, naar det gjaldt, at frygte den offentlige Mening.

Da der i Krigsraadet 4. Febr' af en Deltager var blevet slaaet paa, at man dog, ved hvad man her besluttede, burde tage under Overvejelse de Forventninger, Nationen nærede til det ved Danevirke opstillede Forsvar, havde de Meza svaret: "Vi staar ikke her for at give en Forestilling, der kan vinde Tilskuernes Bifald, vi er her for at benytte de til os betroede Stridskræfter paa den Maade, der bedst forer til Maalet«, og dette Svar var kommet til Kongens Kundskab.

Naar derefter ikke blot den uvidende Mængde, men ogsaa den $i$ sin personlige Magtfolelse skuffede

1) Se Chr. E. Reichs Daghog for 1864 19\%, D. Mag. 6 R. II, $1 \gamma 1 \mathrm{ff}$. 
Krigsminister gik angrebsvis til Værks imod Generalen, var det Kongens Opgave at træde beskyttende til, saa meget mere som hans til Tider stærkt eksalterede Konsejlspræsident ${ }^{1}$ ) med Iver foreholdt ham, at det af indrepolitiske Grunde var nødvendigt at give Generalen Afsked. Hvilket demoraliserende Indtryk vilde dette ikke gøre i Hæren! Det kunde umuligt være klogt hverken $i$ det korte eller det lange Løb paa dette eller andre Omraader at lade Uretten sejre.

Kongen blev styrket $i$ sin Beslutning ved Meddelelsen om, at der til ham vilde indgaa et Andragende fra samtlige i de overste Kommandoposter ved Dybbøl ansatte Officerer om snarest muligt at faa General de Meza tilbage i Overkommandoen. Andragendet var tiltraadt af selve den midlertidige Overgeneral, hvem Andragendet reglementsmæssigt havde passeret, og det skulde nu gaa den tjenstlige vej gennem Krigsministeriet. Men her blev det standset, officielt kom det aldrig til Kongen. Krigsministeren gav tværtimod efter nogle Dages Forløb de andragende højtstaaende Officerer en skarp Tilrettevisning for deres Indblanding $i$ et Spørgsmaal, der laa helt udenfor deres Raadighedsomraade.

Krigsminister Lundbye kunde gøre dette, fordi han i Mellemtiden havde faaet sine egne usikre Forhold bragt $\mathrm{i}$ Lave. Han havde varet nødt til at forelægge Kong Kristian Valget mellem ham som Krigsminister og de Meza som Overgeneral, og Kongen havde ikke et Minut været $\mathrm{i}$ Tvivl om, at han vilde vælge den

1) H. T. ช H. V, 81). 
sidste $\operatorname{Ldvej}^{1}$ ). Men saa optraadte Konsejlspræsidenten.

Monrad havde hidtil overfor Majestæeten efter sin egen Mening været tilbageholdende i Spørgsmaalet om de Meza. Det havde for ham været som Svien i Saar. Han skulde her tilføje den af Land og Rige i saa høj Grad fortjente Hærfører en Lret, der tilmed, stærkt til Aars som denne Mand var, for hans Vedkommende vilde forblive uhjælpelig, og i denne Uret - dette smertede ham maaske endnu mere - skulde han inddrage de Mezas kloge Stabschef, ${ }^{2}$ ) den Officer, som ved Ord og Holdning havde givet ham en Forstaaelse af, hvad Krig og Kommando var, som han aldrig vilde miste. Men han kunde ikke andet. Han formaaede ikke at lose den Opgave, der af Forsynet var blevet ham betroet, hvis han i Sporgsmaalet Meza valgte at gaa med Kongen imod, foruden $i$ det væsentlige sit eget Ministerium, det. Flertal af Befolkningen, der hidtil havde haft den afgørende Indflydelse paa Bestemmelsen af Danmarks Skæbne, og som var lidenskabelig besluttet paa at bevare denne Indflydelse. Den Omstændighed, at dette Flertals Opfattelse her beroede paa en Fejltagelse, var det ham jo forlæengst klart kunde ikke være afgørende. Opgivelsen af Danevirkestillingen var en Gang for alle at betragte som en symbolsk Handling: De, som billigede Tilbagetoget, var de i

1) Den franske (iesandt i Kubenhavn Dotézac fortadler i en Indberetning til sin Chef Drouyn de Lhuys af $1 \times(i 46 / 3$, at han paa en Spadseretur har modt Kong Kristian 4 , som opfordrede ham til at slaa Folge, og at Kongen for ham bl. a. har udtrykt la tristesse profonde, avec laquelle il a du céder à la volonté du Cabinet demandant la destitution du général Meza. Les origines II, 90.

2) D. G. Monrad. Politiske Breve. Nr. 1 4. (f7. 
national Henseende ligegyldige, de, der angreb det, var de af Tanken paa deres danske Fædreland grebne. Ve den, der gik mod disse sidste!

Og nu med et, lige som ved en højere Styrelses Medvirken, gav Begivenhederne ham Løsningen af den haarde Knude i Hænde. General Meza's sidste Optræden over for Krigsministeren gjorde Generalen umulig som Hærfører: efter dette Brev var det ikke til at overse, hvad han i en eller anden ny krænket Stund kunde forlange som Oprejsning. Og desuden: fik Meza nu Medhold, vilde det, saaledes som Sagen var drevet paa Spidsen, bortset fra alt andet, betyde en saa stor Sejr ikke blot for ham personlig, men for Hærens Overkommando nu og bestandig, at den virkelige Overledelse af Krigen og dermed af Landets Stilling mellem Staterne vilde glide ud af Regeringens Hænder og havne i Generalernes Raad. Ministeriets Chef maatte her skride ind.

Monrad havde lige saa lidt som Krigsminister Lundbye Blik for den moralsk odelæggende Virkning, som denne Fjerneise af Overgeneralen maatte faa paa Hærledelsen - og Lammelsen i 1864 af vor Overkommandos Selvtillid og Foretagsomhed kom os i Virkeligheden dyrt at staa -, og med sin hurtige Vilje til at anse for rigtigt, hvad der i det givne Øjeblik passede ham, oversaa han nu, hvad han ellers fuldt ud anerkendte, i det mindste i Teorien, den Forskel, der var og altid maatte være, paa de Beslutninger, der $i$ Krigens afgørende Øjeblikke skulde tages af den kommanderende ved Fronten, og de Bestemmelser angaaende Krigens Maal og Mening, som hørte hjemme i Statsraadet. 
Monrad stillede sig altsaa ved Krigsministerens Side og gjorde dennes Forbliven i Ministeriet og General de Mezas endelige Fjernelse fra Overkommanmandoen til et Kabinetsspørgsmaal. Han beregnede, at han herved ikke satte meget $i$ Vove, Kongen vilde ikke kunne finde en Mand, der vilde være i Stand til at danne et Ministerium med General de Mezas Genindsættelse $i$ sin Post som Programhandling. Og vel vilde hans Forhold til Kongen, lidet godt som det desværre var blevet, ved denne hans Optræden yderligere lide Skade - hvilket var en Skæbnens Ironi, idet den Regeringsbeslutning, han ved sin Handlemaade vilde frentvinge, meget mulig vilde blive den, der reddede Dynastiet Glücksburg fra Fald - men der skulde og vilde for ham blive Lejlighed til at vinde den tabte Gunst tilbage! Tiden var for stor til, at han skulde falde for et personligt Lapperis Skyld, og andet var der her til syvende og sidst ikke Tale om.

Uhensigtsmæssigt vilde det i denne Anledning ikke være at benytte den sig frembydende Lejlighed til over for Kongen og dennes Omgivelser en Gang for alle at vise den skarpe Klo. Han havde hidtil været for blød baade $\mathrm{i}$ Adfærd og Tænkemaade.

Lordag 27. Febr. havde Kongen til endelig Overvejelse Bestemmelsen angaaende de Meza's og Ministeriets Skæbne, og Monrad skulde samme Dag i Landstinget besvare en Forespørgsel, der i høj Grad berørte dette Anliggende, nemlig Spørgsmaalet om, hvorvidt Danevirkesagens Aktstykker i en nær Fremtid kunde blive tilgængelige for de lovgivende Forsamlingers Medlemmer. Parlamentarisk Sædvane og Sømmelighed paabød Monrad ved dette tilfældige 
Sammentræf at sørge for, at han blev fritaget for at besvare Foresporgslen netop denne Dag, enten ved, at den toges ud af Dagsordenen, eller, hvis ikke det let lod sig gøre, ved, at der gaves ham Lejlighed til $\mathbf{i}$ Korthed at erklære i Tinget, at Sagen ikke var endelig afgjort, som Forudsætningen var, da Besvarelsen af Forespørgslen berammedes til denne Dag, men at den ventelig snart vilde blive det, og at Ministeren da, for saa vidt han til den Tid fik med disse Ting at gøre, skulde stille dens Akter til de Herrer Medlemmers hensynstagende Raadighed.

Men i Stedet for at indtage en saadan Holdning, indlod Monrad sig paa selve det brændende Sporgsmaal og gav sig til ordrigt at meddele, at "de to Mænd, Overgeneralen og Krigsministeren« var kommet $i$ et saadant Forhold til hinanden, at de umuligt kunde arbejde sammen sefter mit Skønnende derved, at den Mand, hvem Overkommandoen har veret betroet [saaledes betegnede Monrad nu den Mand, han 7. Februar wbeundrede«], dels har omgaaet Krigsministeren og dels har stillet sig over ham«. "Spørgsmaalet foreligger nu", fortsatte Ministeren, "til Kongens Resolution, og jeg er overbevist om, at hvad Resultat Hs. Majestæt end maatte komme til med Hensyn til dette Spørgsmaal, saa vil der ikke kunne være Tale om andet, end at Armeen med fuldkommen Tillid vil modtage Hs. Majestæts allerhøjeste Beslutning ${ }^{1}$ ). Da det vil være urimeligt at antage, at der med denne sidste Floskel ikke skulde være ment andet end den Selvfølgelighed, at Hæren ved ethvert lovligt Paabud fra oven vilde lystre, ligger det nær at

1) Rigsdagstidende 1X(i4. Landst. Forh. Sp. 719. 
forklare Ytringen derhen, at Monrad modsætningsvis har villet slaa paa og minde Kongen om, at der uden for Hæren stod et Folk, der ikke vilde taale de Meza i Spidsen for Forsvaret, og at Hs. Majestæets Konsejlspræsident havde sagt ham det og stillet sig paa bred fælles Grund med det Samfund, det laa $i$ Kongens dyreste Interesse at vinde. Hs. Majestæt vilde derfor allernaadigst behage at se sig vel for, naar Allerhøjst Samme i disse Dage tog en Beslutning.

Monrad lagde derefter Sigtet mod de Herrer ved Hove, militære og andre, som havde Kongens Øre. Det var blevet ham meddelt, fortalte han, at en hojtstaaende Officer - Navnet havde han ikke faaet at vide - skulde have ytret, at hvis denne Sag fik en Afgørelse, som ikke stemmede med hans, Officerens, Ønske, maatte han forlange sin Afsked. Ministeren vilde imidlertid benytte Lejligheden til her "gennem Offentligheden « at svare denne Officer, at skulde Tilfældet indtræde, vilde han anse en Afsked uden Pension for at være "en overordentlig mild, ja maaske en meget for mild Behandling «, og Tinget, der, samtidig med at det med en vis Beklemmelse havde været Vidne til Ministerens Brud paa god Tone i det nære Forhold mellem Landets høje og allerhøjeste Myndigheder, begærlig havde taget imod de Oplysninger, Monrad med Omsigt havde givet til Bedste, fik her Luft i forskellige Bifaldsraab. Det gjorde derved Fyldest for den Hensigt, hvormed disse Bemærkninger var blevet fremsat. De Herrer ved Hoffet og i Nærheden deraf skulde have at vide, at der overfor dem stod en Mand, som ikke havde $i$ Sinde at lægge Fingrene imellem, hvis de kom ham paa tværs, og at selv det forholdsvis varsomme Landsting i saa Henseende villig stottede ham. 
Lidt over en Time efter den her skildrede Tildragelse i Rigsdagens Førstekammer stod Monrad højtidelig ved Kongens Side i den blaa Sal paa Christiansborg for som Majestætens mest betroede Raadgiver at bistaa denne ved Modtagelsen af den samlede Rigsdag, der under Udfoldelsen af et stilfærdigt Ceremoniel paa denne Dag overbragte Kongen en Adresse og modtog det Svar, Kongen gav sin tro Rigsdag ${ }^{1}$ ). Var der ikke hos Ministeren under disse Omstændigheder en ubehagelig Følelse forbunden med Udførelsen af hans officielle Gerning, men tværtimod nu som altid og nu maaske netop mere end ellers stærk sjælelig Tilfredsstillelse, var det Ubehag, Kong Kristian følte ved situationen, saa meget desto storre.

Rygtet havde paa sine rappe Fodder haft Tid til saa nogenlunde at sætte Kongen ind $i$, hvorledes han med Omgivelser nys var blevet taget under offentlig Behandling af Ministeren og desværre, det var ham ikke muligt at give det Svar, der ene passede til Begivenheden. Der var ikke Aflosning at finde for Ministeriet Monrad. Men kunde Majestæen ikke nu anmode sin Konsejlspræsident om med samtlige sine Folk at vige Pladsen, kunde han gore noget andet.

Dagen efter, Søndag 28. Febr., om Aftenen underskrev Kongen med tungt Sind den Resolution, i Følge hvilken Krigsministeren fik Bemyndigelse til at meddele General de Meza's Afsked fra Overkommandoen, men i denne Bemyndigelse, der var formet som et Svar paa den af Krigsministeren fremsendte Indstilling om Generalens Afskedigelse lod Kongen indsætte: "Efter hvad Du... har anført om det Forhold, der .... har udviklet sig mellem Dig og Generalløjtnant

1) Dagbladet $1864: 29 / 2$. 
de Meza, og som.. gor det umuligt for Dig.. fremdeles at betro ham Posten som den aktive Armees kommanderende General, vil Vi, i $B$ e trag t $\mathrm{n}$ ing af a vor Konsejlspræsident har gjort Din Forbliven i Ministeriet til et Kabinetsspørgsmal for sitvedkom mend $e^{1}$ ), herved meddele Vort Samtykke til, at Generalløjtnant de Meza definitivt fratræder Overkommandoen.... $\ll^{2}$ ) og Kristian 9. fik ved denne aldrig før eller senere benyttede Vending $i$ en kongelig Tilkendegivelse med god Vilje Ram paa den i denne Tildragelse mest skyldige.

General de Meza traadte da i yderlig Grad smertelig ramt ${ }^{3}$ ) tilbage til den Stilling som kommanderende General paa Sjælland, han havde haft for Krigen, og hverken under Krigsminister Lundbye eller under dennes Efterfølger i Krigstiden eller under den derpaa følgende Krigsminister, som fik Lejlighed til baa-

1) Udhærelsen findes ikke i det originale Dokument.

2) Generalstaben: Den dansk-tyske Krig 1864 I, 323.

3) General de Meza forfattede i Sommeren 1865 nogle Maaneder for sin Dod en Henvendelse "Til Medborgere", der dog ikke da blev offentliggjort. "Svogeren Tscherning, til hvem Aktstykket var blevet overgivet, holdt det tilbage, rimeligvis fordi han fandt, at dets Form for meget har Præg af Forfatterens Alder og Svagelighed. Henvendelsen har dog ikke ringe personalhistorisk Interesse. Den begynder saaledes:

»Landsmænd og Medborgere af alle Klasser og Stænder! Man har skammeligt fort Fder bag Lyset med Hensyn til den sande Sammenhæng af min Harforelse i Begyndelsen af 1864! Disse Ond til Eder skulle ingen Und-

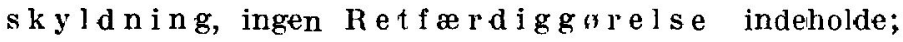
jeg behøver dem ikke; min Sag er og vil altid blive ren og k lar for alle dem, der elske Sandhed og Retfard. Men jeg kan ej onske andet, end at I erkjender Sandheden, og siger Eder den her som sidste Farvel fra den, der st e d se, saavel i 1864 som i $1848-49$ og 50, varmt elskede 
de, med Ere, at afskedige Generalen ved Hærreduktionen i Efteraaret 1864 og til et Aarstid efter at folge de Meza til Graven, var der Tanke om at rejse Anklage imod ham for hans Forhold ved Danevirke. Tværtimod! Kong Kristians og samtlige dalevende høje Officerers Dom om hans Handlemaade ved den Lejlighed blev Krigsbestyrelsens og Eftertidens.

Monrad indlod sig aldrig paa umiddelbart at anfægte denne Dom, men lige som han fra første Færd i denne Sag havde taget sine Forholdsregler i Henhold til Opinionen, blev han ved dermed. Han offentliggjorde ik ke Grunden til de Meza's Afskedigelse, og da senere Danevirkesagens Aktstykker blev fremlagt i Rigsdagens Bureau til Medlemmernes Undersøgelse, var den kongelige Resolution med dens Fremhævelse af „Vor Konsejlspræsidents« særegne Delta-

Armeen, Eder og sit Fædreland, og ansaa det for sin Stulthed og Lykke, i en og samme uadskillelige Ihardighed at omfatte alle tre..

Efter at have rettet et kraftigt stud mod sine nationalliberale og skandinavisk sindede Forfolgere og efter dernast bl. a. at have givet en Meddelelse om sit forhaands Kendskab til Danevirkestillingens Svagheder fortsatter han: "Men vel var det $\mathrm{mig}$, der trods alle disse Misligheder overtog et Kommando, hvis Forelses Natur saa let - det indsaa jeg fuldkomment — i sine Folger kunde mistolkes; overtog den, fordi den ikke blot m a a t t e overtages af nogen men overtages af en, der havde Mod til ligeoverfor Uforstandiges og Ildesindedes forvirrede Raab, at frelse Armeen og opbevare den til fornuftigere Virksomhed, end den fortsatte Forbliven paa en uholdelig Operationslinie, som man havde udgivet for uind tage lig, tilbod, og jeg skal uanset al den Forfolgelse, ja offentlig Spot og Ydmygelse, for hvilke dette Skridt i Labet af mere end et Aar daglig har udsat mig, ingensinda fortryde det."

Kort derefter slutter Henvendelsen. 
geise i Afgørelsen ik k e blandt disse Dokumenter ${ }^{1}$ ). Enhver kunde, efter som det passede ham, danne sig sin Mening om Begivenheden, og de fleste havde ikke Midler til at faa andet ud af Sagen, end at den var faldende for de Meza og overmaade sørgelig for Danmark.

Det vakte derfor stor Forundring, da Monrad efter sin Minjstertid i Slutningen af August 1864 som menigt Medlem af Folketinget i det da endnu samlede Rigsraad under Forhandlingerne i et Møde og i Fortsættelse af ot vredt Modstød, han havde rettet mod en for ham og hans afgaaede Ministerium ugunstig Udvalgsindstilling, polemisk oplyste, at Krigsminister Lundbye, "der stod Begivenhederne saa nær«, end jkke havde trenkt paa i Anledning af Tilbagetoget fra Danevirke at stille General de Meza for en Krigsret. Man betvivlede ikke Oplysningens Rigtighed, men Forklaringen matte altsaa ligge i, at Krigsministeren som "svag Mand" ikke havde villet "gøre sin Mening skarpt galdende" overfor den Magt $\lfloor$ : Kongenj, der havde støttet Generalen, hvilken Forklaring Monrad til Trods for sin bedre Viden ikke indlod sig paa at modsige.

Og 10 Aar efter spørger Monrad i et af sine den Gang meget omtalte, i Berlingske Tidende offentliggjorte Politiske Breve, hvori han efter den Anledning, der var givet ham, ikke kunde undlade at betegne Opgivelsen af Danevirkestillingen som sfuldt berettiget«, med en underlig stakaandet Tilrettelægning af Sagen: "Kan man sige, at General Meza var et Offer?" Allerede i Spørgsmaalet hører man Efterdønningen af de mange Aars stødvis kommende Over-

1) Dagbladet $186416 / 3$ 
vejelser, og Svaret? Ja, det er i sin paafaldende Mangelfuldhed intet mindre end Blottelsen af en daarlig Samvittighed ${ }^{1}$ ) den ufrivillige Bekendelse af Skyld, der, saa længe denne Sag overhovedet mindes, vil være uadskillelig fra Monrads Adfærd overfor de Meza.

Den daværende Biskop giver 30. Maj 1874 i følgende Ord sit Svar paa det af ham selv opstillede Sprrgsmaal: "Jeg tror, at det vil være et Misbrug af denne Benævnelse ["et Offer"] at kalde ham saa. Man tjener Fædrelandet saa længe, dette har Brug for ens Kræfter, og man bliver ikke noget Offer, fordi der indtræder et Tidspunkt, hvor Brugen af andre Kræfter synes mere hensigtsmæssig. General Meza beholdt til det sidste sin Konges trofaste Naade; den Egenskab hos Kongen, at hans Velvilje ej slipper den Mand, der har tjent ham efter bedste Evne, selv om Landet ikke længer har Brug for hans Tjeneste, og selv om hans Anseelse synker $i$ det almindelige Omdømme, er kommet ikke faa iil gode $\left.\aleph^{2}\right)$. Dette er Ordene, der er ikke flere.

Monrad har ved Sammenstillingen af disse Sætningers aabenlyse Tomhed ikke et Minut for Alvor tænkt paa at klarlægge noget som helst angaaende de Meza. Han har, formodentlig for hundrede Gang, faaet en Jævnføring mellem sin og de Mezas Skæbne i Tanke, og han har da ikke kunnet holde tilbage et Suk over, at der i hans Livslod manglede Kongens Naade - dette skulde dog ingen Magt paa Jorden faa ham til at tilstaa (han fremhæver i sin "Redegørelse" det modsatte) - og han har dernæst med den Evne,

1) Rigsraadstidende 1864 Folket. Forh. Sp. 1466-1467, $1485-1486$.

$\left.{ }^{2}\right)$ D. G. Monlad: Politiske Breve Nr. 1-4, 66-67. 
han besad til ikke at give til Kende »alt, hvad han mente«, i 1874 som i 1864 villet tilsløre den Tragedie, det $i$ Danevirkesagen faldt $i$ hans Lod at lade foregaa i Virkelighedens Verden. Som ung Mand havde han formaaet at lade de gammeltestamentlige Syner i sin digtede Tragedie forsvinde fra sin Tilværelse, skulde han ikke nu kunne mane fra sig denne i den samme Virkelighed, oplevede Tildragelse? Nu vel: General Meza var ikke et Offer!

Og virkeligt, det synes, som om Monrad tilsidst fik Ro for dette pinende Spørgsmaal. I sin 6 Aar senere nedskrevne "Redegørelse" for sin Deltagelse $i$ Begivenhederne 1864 behandler han undagelsesvis netop denne Sag fra et overlegent Standpunkt. Ellers mangler der ikke Forfatteren af dette Tilbageblik Lyst til Selvanklage, men ved Tanken paa Anliggendet de Meza bliver Monrad i sit halvfjerdsindstyvende Aar ligefrem i godt Humør. Han skriver om Mellemværendet mellem Krigsminister Lundbye og General de Meza: "Jeg skønnede [den Gang], og jeg skønner ej heller nu rettere, end at Krigsministeren havde fuldstændig Ret«, hvorved han dog efter Sammenhængen til Trods for Fremstillingens Fortielser og Fordrejelser maa mene: »i den disciplinære Del af Striden«. Det fremgaar imidlertid af hele Sammenhoongen, at Monrad i Overensstemmelse med sin tidligere Holdning i denne Sag har ønsket, at det logisk underforstaaede og nogle Sider foran i "Redcgorelsen « fremhævede ${ }^{1}$ ) skal undgaa de ikke sagkyndige Læseres Opmærksomhed, saa at Stedets Mening for

1) De Mænd, hvem Danevirkes Rumning skyldes, ville, skint den liang haanede, blive kransede af Historien. D. F. Monrads Deltagelse 63. 
dem bliver en Forsikring af Monrad om, at Krigsminister Lundbye $i$ et og alt har haft Ret overfor General de Meza. Det følgende vil $i$ andet Fald hvile paa en for ufornuftig Forudsætning. Det lyder i sin Gammelmandslystighed uden videre saaledes: "Det var heldigt, at Retten her stemmede saa godt overens med det i politisk Henseende onskelige«, d. v. s. de Mezas Fald ${ }^{1}$ ).

Ja sandeligt, blot omvendt! Det vilde have været "heldigt", om Monrad i Februar $181 ; 4$ havde ladet det i politisk Henseende ønskelige stemme overens med Retten! Fastheden i Hærens Førelse var da ikke blevet brudt, og det danske Folk var i Tide blevet belært om Alvoren i det politiske Vovespil, det som i Leg havde indladt sig paa, og frem for alt, Monrad vilde være bleven en anden end den Famler, han viste sig at være $i$ de store Ting. Hans Vilje vilde da have sat ham det vanskelige Maal at overvinde Folkestemningen, men den aandelige Kraft, han besad, vilde have drevet ham i Kampen for at naa dette Maal saa langt frem, at hans Navn, hvad der end iøvrigt var sket, nu havde været omstraalet af Hæder.

Saa langt frem kom Monrad altsaa ikke.

1) D. (i. Monrads Deltagelse 69 0 (1). 